This article was downloaded by: [B-on Consortium - 2007]

On: 4 December 2009

Access details: Access Details: [subscription number 908038074]

Publisher Taylor \& Francis

Informa Ltd Registered in England and Wales Registered Number: 1072954 Registered office: Mortimer House, 3741 Mortimer Street, London W1T 3JH, UK

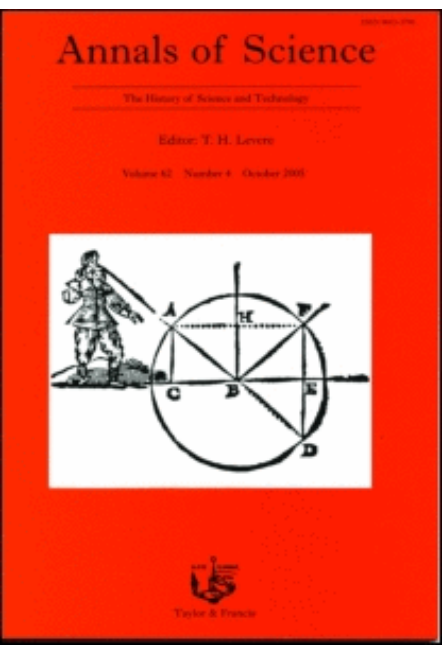

\title{
Annals of Science
}

Publication details, including instructions for authors and subscription information:

http://www.informaworld.com/smpp/title content=t713692742

\section{The Emergence of New Scientific Disciplines in Portuguese Medicine:} Marck Athias's Histophysiology Research School, Lisbon (1897-1946)

Isabel Amaral ${ }^{\text {a }}$

${ }^{a}$ Centre for the History and Philosophy of Science and Technology, Faculty of Science and

Technology, New University of Lisbon, Caparica, Portugal

To cite this Article Amaral, Isabel'The Emergence of New Scientific Disciplines in Portuguese Medicine: Marck Athias's Histophysiology Research School, Lisbon (1897-1946)', Annals of Science, 63: 1, 85 - 110

To link to this Article: DOI: $10.1080 / 00033790500429425$

URL: http://dx.doi.org/10.1080/00033790500429425

\section{PLEASE SCROLL DOWN FOR ARTICLE}

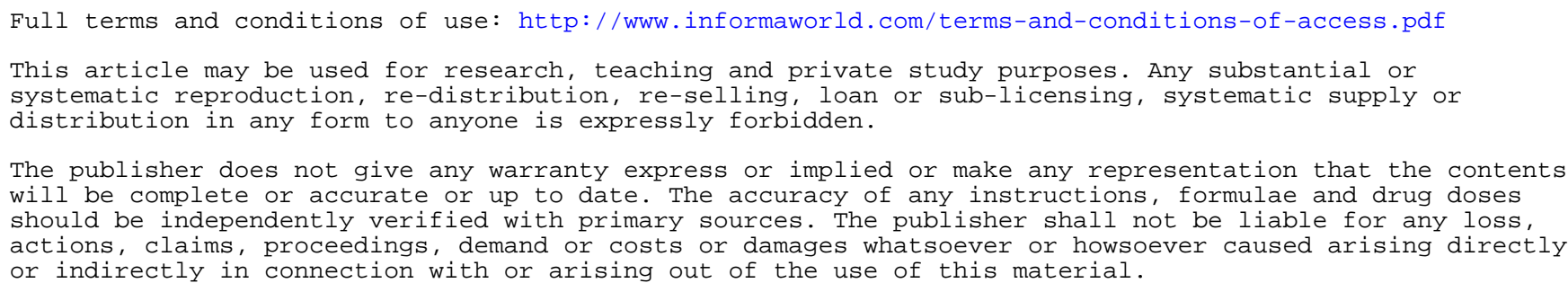




\title{
The Emergence of New Scientific Disciplines in Portuguese Medicine: Marck Athias's Histophysiology Research School, Lisbon (1897-1946)
}

\author{
ISABEL AMARAL
}

Centre for the History and Philosophy of Science and Technology, Faculty of Science and Technology, New University of Lisbon, 2829-516, Caparica, Portugal

Received 23 May 2005; Revised paper accepted 13 October 2005

\section{Summary}

This paper discusses the emergence of new medical experimental specialties at the Medical School of Surgery (Escola Médico-Cirúrgica) and the Faculty of Medicine of Lisbon University (Faculdade de Medicina da Universidade de Lisboa) between 1897 and 1946, as a result of the activities of Marck Athias's (1875-1946) histophysiology research school. In 1897, Marck Athias, a Portuguese physician who had graduated from the Faculty of Medicine in Paris, founded a research school in Lisbon along the lines of Michael Foster's physiology research school in England and Franz Hofmeister's physiological chemistry school in Germany. His research programme was highly innovative in Portugal. Not only did it bring together many disciples and co-workers, but it branched out and created new medical specialties within Portuguese medical science. These new disciplinary areas grew out of the study of the histology of the nervous system but eventually expanded into normal and pathological histophysiology, physiological chemistry and experimental endocrinology. The esprit de corps that existed between research school members ensured the school's success and influence in various fields social and political as well as scientific. Athias's school was strongly influenced by positivist ideals and promoted a teaching and research style that sought inspiration in Humboldt's university model, thus helping to bring about a change in the dominant scientific ethos and to modernize scientific research in Portugal during the first half of the twentieth century.

\section{Contents}

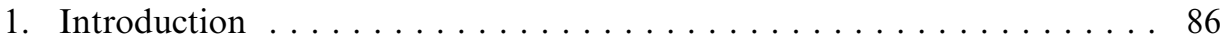

2. Marck Athias: A short biography ................... 88

3. The disciples . . . . . . . . . . . . . . . . . . . . . . . . . 94

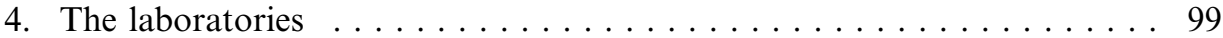

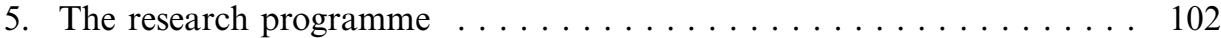

6. The school's role in the scientific community and in society: Ideology and practice ...................... 103

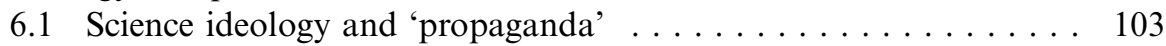

6.2 Involvement in active politics . . . . . . . . . . . . . . . 108

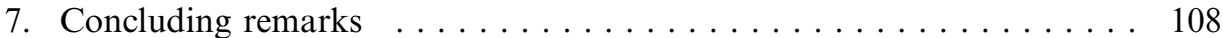




\section{Introduction}

Athias fought against what often seemed insurmountable difficulties. At one stage in his career, he had to scale down his activities as he was unable to gather enough support for his work and the institutions he worked in ... but despite all this ... his endeavour was not in vain, it started a tradition and a number of disciples carried on his work. (Augusto Celestino da Costa, 1948)

The perception of what a research school is has varied over time. ${ }^{1}$ The term 'research school' was coined in 1904 by J. T. Merz, who was thinking of the research centres that had been created in nineteenth-century European and American industrial laboratories ${ }^{2}$ in order to place scientific research at the core of universities' activities and thus contribute to the recognition and professionalization of scientific activities. In 1969, O. Hannaway supported Merz's view in his analysis of M. P. Crosland's study of the Société d'Arcueil ${ }^{3}$ by associating research schools with the professionalization of science in the nineteenth century. ${ }^{4}$ For this author, the term suggested a model in which disciples would model their research upon that of their leader. Research projects were discussed collectively, and their development contributed to the gradual expansion of the school's research programme.

From Merz's time to Hannaway's, the term 'research school' was not commonly used, but it has since become widespread, and many authors have provided in-depth discussions and attempted to systematize the term. The best-known models are those of J. Morrell ${ }^{5}$ and G. Geison. ${ }^{6}$

Morrell's work was published in 1972 and provided a series of criteria for a discussion of research schools. It was based on a study of two schools that emerged from within university laboratories, Justus Liebig's (1803-73) and Thomas Thomson's (1777-93) schools of chemistry. The cognitive, social, and material criteria proposed by Morrell were later systematized by Geison, contributing to the definition of research school that is best known and most commonly used by historians. $^{7}$

The study of research schools contributes to a deeper understanding of the emergence of specialties and new disciplines, as well as their role in innovation or paradigm shifts in well-established disciplines, an example of which is Michael Foster's school of physiology at the University of Cambridge. ${ }^{8}$

\footnotetext{
${ }^{1}$ For a detailed discussion of the historical evolution of the 'research school' concept, see John W. Servos, 'Research Schools and Their Histories', Osiris, 8 (1993), 3-15.

2 John T. Merz, A History of European Thought in the Nineteenth Century (London, 1904), 204.

3 Maurice P. Crosland, The Society of Arcueil: a View of French Science at the Time of Napoleon I (Cambridge, 1967).

${ }^{4}$ O. Hannaway, 'Review of Maurice Crosland, The Society of Arcueil: a View of French Science at the Time of Napoleon I', Isis, 60 (1969), 578-81.

5 Jack B. Morrell, 'The Chemist Breeders: The Research Schools of Liebig and Thomas Thomson', Ambix, 19 (1972), 1-46.

${ }^{6}$ Gerald L. Geison, 'Scientific Change, Emerging Specialties, and Research Schools', History of Science, 19 (1981), 20-40.

7 According to Geison, a research school is a "small group of mature scientists pursuing a reasonably coherent program of research side-by-side with advanced students in the same institutional context engaging in direct, continuous social and intellectual interaction'. G. Geison, op. cit. (6), p. 23.

Gerald L. Geison, Michael Foster and the Cambridge School of Physiology: the Scientific Enterprise in late Victorian Society (Princeton, NJ, 1978).
} 
Various research schools have been studied along the lines suggested by the above-mentioned authors, ${ }^{9}$ and such studies have shown that they are usually the locus for the emergence of new specialties. Geison considers that certain schools have played a pivotal or catalytic role in such processes. Amongst such schools, he includes Liebig's school of chemistry at the University of Giessen (1824-52) ${ }^{10}$, which played a central role in the emergence of organic chemistry, Noyes' research school at CalTech (1920-36), which acted as a catalyst in the development of physical chemistry in the USA, ${ }^{11}$ and Fermi's research school at the University of Rome (1926-35), which is associated with the emergence of nuclear physics. ${ }^{12}$

More recently, other authors have proposed alternative names to Geison's research school, such as Joseph Fruton's research group ${ }^{13}$ or F. M. Andrews's ${ }^{14}$ research unit.

None of the models that have been put forward for a discussion of research schools provides a comprehensive interpretation of all the variables involved in specialization processes in contemporary science. ${ }^{15}$ This paper is not intended to be an exhaustive analysis of the processes that led to the emergence of the aformentioned medical sub-disciplines. Instead, the notion of research school/research group put forward by Geison and Fruton will be applied to the research school led by Marck Athias. ${ }^{16}$

Athias's research laboratory qualifies as a research school in various ways: he was a respected leader; he implemented a sufficiently coherent research programme; he gathered together a group of motivated students and collaborators; he possessed appropriate research facilities and funds; he used reliable experimental techniques; he created his own channels for the dissemination of his school's scientific production, and he had a political agenda which he realized through the definition of research

\footnotetext{
9 Studies undertaken using Geison's criteria include, e.g: Alan J. Rocke, 'Group Research in German Chemistry: Kolbe's Marburg and Leipzig Institutes', Osiris, 8 (1993), 53-79; Jack Morrell, 'W.H. Perkin, Jr, at Manchester and Oxford: from Irwell to Isis', Osiris, 8 (1993), 104-26; Juan M. Sánchez-Ron, and A. Roca-Rosell, 'Spain's First School of Physics: Blas Cabrera's Laboratorio de Investigaciones Físicas', Osiris, 8 (1993), 127-55; P. M. Menson, 'The Comstock Research School in Evolutionary Entomology', Osiris, 8 (1993), 159-77; James A. Secord, 'The Geological Survey of Great Britain as a Research School (1839-1855)', Hist. Sci., 24 (1986), 223-75, and Joseph S. Fruton, Contrasts in Scientific Style-Research Groups in the Chemical and Biochemical Sciences (Philadelphia, PA, 1990).

${ }_{10}$ Another source for Liebig's Giessen school is Joseph Fruton, op. cit. (9).

11 John W. Servos, 'The Knowledge Corporation: A. A. Noyes and Chemistry in Cal-Tech, 1915-1930', Ambix, 23 (1976), 175-86.

12 Gerald Holton, 'Fermi's Group and the Recapture of Italy's Place in Physics', in The Scientific Imagination: Case Studies (Cambridge, 1978), pp. 155-98.

${ }_{13}$ Joseph S. Fruton, 'Contrasts in Scientific Style - Emil Fischer and Franz Hofmeister: Their Research Groups and Their Theory of Protein Structure', Proceedings of the American Philosophical Society, 129 (1985), 313-70; Joseph S. Fruton, 'The Liebig Research Group-A Reappraisal', Proceedings of the American Philosophical Society, 132 (1988), 1-49.

14 For Andrews, the notion of research unit is identical to J. Fruton's research group. Frank M. Andrews (ed.), Scientific Productivity: The Effectiveness of Research Groups in Six Countries (Cambridge, 1979).

${ }^{15}$ Ludwik Fleck is one of several authors who have warned against the adoption of a one-sided approach to the study of the emergence of new specialties, arguing that there are many factors that can play a decisive role in such processes. Ludwik Fleck, Genesis and Development of a Scientific Fact (Chicago, 1979), pp. 14-15. His views are shared by Ana Carneiro, who believes that the proposed models should be used by historians as guides in the study of small communities of innovating scientists and not as conceptual grids to be applied rigidly. Ana Carneiro, The Research School of Chemistry of Adolphe Wurtz, Paris, 1853-1884 (Canterbury, PhD thesis, 1992).

16 The research school of Marck Athias has been subject of a wider investigation into the emergence of biochemistry in Portugal. For further details see Isabel Amaral, As Escolas de Investigação de Marck Athias e de Kurt Jacobsohn e a Emergência da Bioquímica em Portugal (Lisbon, PhD thesis, 2001).
} 
policies, the establishment of societies and journals, and in his strategies of popularization.

\section{Marck Athias: A short biography}

Marck Athias was born in Funchal (Madeira Island) to Jewish parents on 11 December 1875 . He completed his primary and secondary studies in Madeira and graduated in medicine from the Faculty of Medicine in Paris in 1897. As a student, he became interested in the histology of the nervous system, in particular the work of Spanish histophysiologist Santiago Ramón y Cajal (1852-1934), ${ }^{17}$ Les nouvelles idées sur la structure du système nerveux (1894). In his third year at university, Athias began collaborating with Mathias Duval (1844-1907), a former student of Cajal and Athias's lecturer on histology. Five papers resulted from this collaboration that helped bring Athias to the attention of the best histologists of his time. ${ }^{18}$

Athias hoped to move to Duval's laboratory after graduating, but he did not get the position and had to return to his hometown. When his father died within a few months of his arrival, Athias felt there was nothing to keep him in Funchal. He dreamt of a research career in a cosmopolitan city and decided to move to Lisbon, since returning to France did not seem a feasible prospect in the wake of the Dreyfus affair (1894) and the ensuing wave of anti-semitism.

Athias arrived in Lisbon in 1897, at a time of considerable political turmoil in the prevailing monarchic regime. The medical community followed any political developments very closely, especially Miguel Bombarda (1851-1910), its leading figure. Bombarda was a psychiatrist ${ }^{19}$ by training and a Member of Parliament, and was strongly in favour of liberal policies. In medicine, this meant advocating a model of medical training that was based on scientific research and not exclusively on books, as was common at the time in Portuguese higher education.

Bombarda invited Athias to run a small histology laboratory at the Hospital of Rilhafoles, in Lisbon, where he worked as a clinician. As a staunch supporter of experimentation in medical education, Bombarda asked Athias to give medical students some initial laboratory training in physiology, Bombarda being in charge of the theoretical course. In the same year, Athias started a course on physiological

\footnotetext{
17 Among many prizes and honours, Santiago Ramón y Cajal was awarded the Nobel Prize in Medicine and Physiology in 1906, together with Camillo Golgi. He gave the Croonian Lecture in London, in 1894, and in Portugal he became an honorary member of the Academy of Sciences of Lisbon (Academia das Ciências de Lisboa).

${ }_{18}$ The five papers published between 1894 and 1897, while Marck Athias worked in Mathias Duval's laboratory, were related to the neuron theory. The importance of this work was acknowledged by Cajal, who quoted it in his own papers. Cf. Augusto Celestino da Costa, 'Marck Athias (1875-1946)', Archives Portugaises des Sciences Biologiques, 9 (1947), 1-4.

19 Miguel Bombarda was culturally sophisticated and had a solid scientific education. He kept up to date with the latest developments in the biomedical sciences and edited the Correio Médico and Medicina Contemporânea, providing the medical community with information on topical scientific issues. However, he did not engage in scientific research. He paid special attention to the subject which he taught - general physiology - because it concerned the problem of life, the origin and evolution of living beings, the general biological functions, and the relationship between mind and body. Bombarda was a staunch supporter of both theories, transformism and a materialism. His book, untitled Consciência e Livre Arbitrio, published in 1898 and reprinted in 1902, was dedicated to Ernst Haeckel, whom he considered 'the founding father of monism'.
} 
techniques which encouraged some students to complete doctoral theses based on experimental research. ${ }^{20}$

From then on, Athias was to lead various research laboratories. Between 1901 and 1911, he worked at various institutions: the Institute Pasteur of Lisbon (Instituto Pasteur de Lisboa); the Medical School of Surgery, and Pestana's Bacteriological Institute (Instituto Bacteriológico Câmara Pestana). ${ }^{21}$

In 1907, Athias founded the Portuguese Society of Natural Sciences (Sociedade Portuguesa de Ciências Naturais) with his disciple A. Celestino da Costa (1884-1956) and his colleague Abel Salazar (1889-1946). This scientific society was followed by the the Portuguese Society of Biology (Sociedade Portuguesa de Biologia) in 1920.

In 1909, following a suggestion by Miguel Bombarda, Athias was asked by the government to undertake a three-month-long tour to visit laboratories and laboratory equipment manufacturers abroad, along with his student A. Pinto de Magalhães. $^{22}$

On 5 October 1910, the First Republic (1910-26) was proclaimed, just a few months after the assassination of Miguel Bombarda. The year 1911 initiated a new phase in Portuguese science. Within three years, the republican regime defined new policies for the development of the country and its colonies. Major landmarks included the reform of the universities, the establishment of a Faculty of Law in Lisbon, the transformation of the medical schools of surgery into faculties of medicine, the creation of separate pharmacy courses, the transformation of the Polytechnic Academy of Oporto (Academia Politécnica do Porto) and Polytechnic School of Lisbon (Escola Politécnica de Lisboa) into faculties of science, the overhaul of the Faculty of Theology of Coimbra University (Faculdade de Teologia de Coimbra) and the Course of Humanities of Lisbon University (Curso Superior de Letras de Lisboa), the establishment of faculties of humanities in Coimbra and Lisbon, and the organization of higher technical education. Despite some shortcomings, this reform opened up the self-contained world of Portuguese higher education. $^{23}$ The statutes of institutions for higher education, adopted in 1911, defined scientific research as a key element. ${ }^{24}$

Marck Athias's research school spans two important periods in twentieth-century Portuguese political history: the First Republic and the Estado Novo (New State) regime, the dictatorship that lasted from 1932 to 1974. The republican ideals favoured the development of the ideas and experimental approach of Athias's research school. The measures adopted by the republican authorities aimed at

20 Duarte Pacheco, Morais Frias, and Cordato de Noronha submitted their doctoral theses during this period. Except for Pacheco, they were jointly supervised by Celestino da Costa. Cf. Duarte Pacheco, Histologia dos Gânglios Espinais (Lisbon, 1905), Morais A. Frias., Contribution à l'Étude des Glandes Paratyröides (Porto, 1910), J. Cordato de Noronha., Contribuição para o Estudo da Hipófise (Lisbon, 1910).

21 Augusto Celestino da Costa, 'O Professor Marck Athias', Folia Anatomica, 10 (1935), 3-10.

22 The role that such tours played in the development of experimental science in Portugal was the topic of a paper presented to the STEP meeting held in Lisbon in September 2000. Isabel Amaral, 'Marck Athias (1875-1946) and Kurt Jacobsohn (1904-1991): Their Travels and the Establishment in Portugal of Laboratory-Based Research in the Bio-Sciences', Science and Technology in the European Periphery, 2nd STEP Meeting: Scientific Travels, Fundação Calouste Gulbenkian, Lisboa, 17-21 de Setembro 2000, pp. $37-38$.

23 José T. Oliveira, 'A Educação em Portugal e o séc. XX', História e Desenvolvimento da Ciência em Portugal, Vol. 2 (Lisbon, 1986), pp. 43-44.

24 Diário do Governo $\mathrm{n}^{\circ} 45,25 / 2 / 1911$. 
reforming medical education, namely the creation of the University of Lisbon (Universidade de Lisboa) in 1911, and of the Committee for National Education (Junta de Educação Nacional - JEN) ${ }^{25}$ in 1929, were therefore instrumental in the development of Athias's research school. The modernization of the university was crucial to the emergence of qualified professionals; the Committee for National Education, which became the State's funding body for scientific research, played a key role in supporting this research. This State body ${ }^{26}$ was established along the lines of Junta para Ampliación de Estudios e Investigaciones Cientifica, ${ }^{27}$ which had been created in Madrid in 1908 and was chaired by Ramón y Cajal, ${ }^{28}$ whose objectives were based on a liberal scientific policy.

Athias replaced Bombarda in the chair of physiology in 1910, and one year later he founded the Institute of Physiology of the Faculty of Medicine of Lisbon (IHFML). In 1919, Athias was appointed Professor of Histology and Physiology as well as director of the faculty's library. The same year, he married Judite Brou, daughter of Aníbal Brou, a doctor who was practising in Oporto. Athias's wife bore him two daughters. ${ }^{29}$

From 1923, Athias divided his scientific activities between the Faculty of Medicine at the Portuguese Institute of Oncology (Instituto Português de OncologiaIPO), where he was responsible for the laboratory of physiology, and the clinical laboratory at the Câmara Pestana Bacteriological Institute.

After the establishment of the military dictatorship in 1926, Athias became a member of JEN, an institution he had helped to create. He chaired JEN between 1931 and 1934. Meanwhile, A. Oliveira Salazar (1889-1970) had become President of the Council of Ministers and the facto ruler of Portugal. Although there are no clear indications of Athias's attitude towards the dictatorship, available information suggests that he did not support it. ${ }^{30}$ The Estado Novo did not favour the activities of Athias's research school. However, it was unable to immediately suppress the tradition that the school had gradually established in the previous period.

\footnotetext{
25 The Committee for National Education (JEN) was a ministerial body that funded and supervised scientific research in Portugal. Its aim was to help improve national education inter alia through the establishment of research centres, scholarships to study abroad and grants for scientific publications.

${ }^{26}$ Dec. Lei n ${ }^{\circ}$ 16:381, Diário do Governo, Ministério da Instrução Pública, 3/1/1929; Dec. Lei n 17:456, Diário do Governo, Ministério da Instrução Pública, 14/10/1929. For more details on the actual decree and the Junta's activities see its first annual report Relatório dos Trabalhos efectuados em 1929-1930 (Lisbon, Junta de Educação Nacional, 1930). The Committee for National Education was replaced in 1936 by the Institute for High Culture. Its task was to promote high culture and the arts, cultural links with foreign nations and scientific research. It was under the Ministry for Portuguese National Education.

27 Gaceta de Madrid, 3/8/ 1925 (offprint), 801-3.

28 For additional information on the establishment of the Junta and its role in the development of science in Spain, see J. Subirá, La Junta para Ampliación de Estudios (Madrid, 1929); María J. Santesmases and E. Muñoz, 'Scientific Organizations in Spain (1950-1970): Social Isolation and International Legitimation of Biochemists and Molecular Biologists on the Periphery', Social Studies of Science, 27 (1997), 187-219.

29 Augusto Celestino da Costa, 'A vida e Obra Científica de Marck Athias', Arquivo de Anatomia e Antropologia, 26 (1948), 144-227.

30 There are no specific data on this issue, but Athias's comments on the national scientific policy suggest that he did not support the regime. Celestino da Costa, for instance, claims that Athias resigned the chairmanship of the Committee for National Education because he did not believe in the role of the institution. This reflects a sceptical attitude vis-à-vis official policy. In Augusto Celestino da Costa, 'Athias e a Investigação Científica', Cadernos Científicos (offprint), 3 (1946), 262.
} 
In 1933, Athias was appointed a professor at the Hydrology Institute (Instituto de Hidrologia), where he carried out research on water samples from various Portuguese spas with medicinal properties. The fact that all these activities and appointments were concentrated in one individual reflects the traditional shortcomings of Portugal's scientific community, characterized by a chronic lack of skilled professionals. In addition, the low wages paid to university teachers and professors also contributed to an accumulation of positions. ${ }^{31}$

For the last fifteen years of his life, Athias worked almost exclusively at the Portuguese Institute of Oncology. He was actively involved in establishing the institution, in various ways: research, directing laboratory work, collaborating on the Bulletin (Boletim), and editing Archives of Pathology (Arquivo de Patologia). He published a number of papers on cancer and actively contributed to the Institute's overall effort in the fight against the disease. ${ }^{32}$ The Institute was the only one which provided him with the necessary means to carry out research on a regular basis.

In 1945, he stepped down as secretary of the Portuguese Society of Natural Sciences and became an honorary member. He remained in the Portuguese Society of Biology until his health worsened. Both the Faculty of Medicine and the Portuguese Institute of Oncology paid tribute to his academic and scientific career with the unveiling of a portrait and a bust by Abel Salazar (1889-1946), ${ }^{33}$ a friend and co-worker. Athias died of cancer the following year, on 30 September 1946.

Athias produced some 138 publications, including scientific papers, teaching materials for his students at the Faculty of Medicine (guides for practical classes in physiology and exercises on chemical physiology), articles for the general public, reports on travels abroad and on the activities of the institutions he chaired, and scientific biographies. ${ }^{34}$ Figure 1 shows the relative proportions of the type of work Athias published.

The thirty-five articles for the general public that make up the second largest group of his publications cover various topics: his views on the foreign countries that he visited to become acquainted with research and teaching in physiology and histology ${ }^{35}$ scientific societies; ${ }^{36}$ the introduction of experimentation in biological

\footnotetext{
31 Augusto Celestino da Costa, A Universidade Portuguesa e o Problema da sua Reforma (Porto, 1918).

32 José A. Guimarães, 'A personalidade do professor Marck Athias', Clínica, Higiene e Hidrologia, 13 (1947), 266-73.

33 Abel Salazar was a doctor and a Full Professor of Histology and Embryology at the University of Oporto, but he also became known as an amateur artist, essayist, historian, and art critic.

${ }^{34}$ He wrote biographies of King Carlos I, Miguel Bombarda, Fernando Matoso Santos, A. Laveran, Santiago Ramón y Cajal, Albert Dustin, Max Askanazy, Henrique Parreira, and Carlos França.

35 Marck Athias, 'Methodos Novos para o Estudo da Estructura do Systema Nervoso', Medicina Contemporânea, 7 (1901), 371-72; Marck Athias, 'O Instituto Solvay de Bruxelas', Medicina Contemporânea, 19 (1901), 346-47; Marck Athias, 'O Ensino da Fisiologia e da Histologia nas Faculdades de Medicina da Bélgica', Medicina Contemporânea, 28 (1909), 357; Marck Athias, 'O Ensino da Fisiologia na Régia Escola de Cirurgia e na Escola Médico-Cirúrgica de Lisboa', Clínica Contemporânea, 6 (1946), 282-341.

${ }^{36}$ Marck Athias, 'La Société Portugaise des Sciences Naturelles', Bulletin de la Société Portugaise des Sciences Naturelles, 1 (1908), 1-10; Marck Athias, 'A Sociedade Portuguesa de Ciências Naturais', Actas do I Congresso Nacional de Ciências Naturais (Lisbon, 1941), v-xvii.
} 


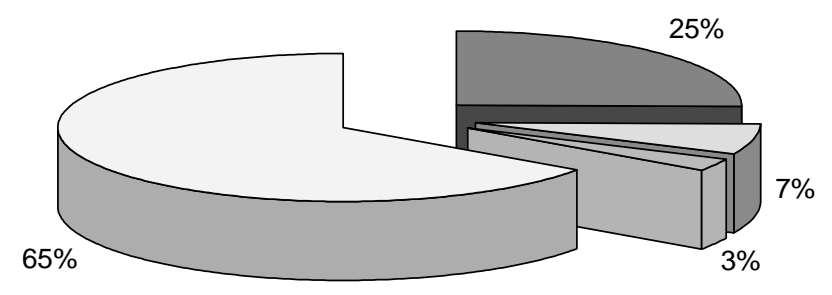

Reports: $25 \% \quad \square$ Biographies: $7 \% \quad \square$ Textbooks: $3 \% \quad \square$ Scientific papers: $65 \%$

Figure 1. Marck Athias's publications between 1895 and 1946.

research $;^{37}$ the fight against cancer ${ }^{38}$ and preliminary work on the disease, ${ }^{39}$ reports on the anti-rabies treatment provided at the Câmara Pestana Bacteriological Institute; ${ }^{40}$ and the scientific papers read at the Bento da Rocha Cabral Scientific Research Institute (Instituto de Investigação Científica Bento da Rocha CabralIRC), which usually summarized a specific topic and were addressed to a specialized audience (albeit with diversified teaching and research interests). ${ }^{41}$

37 Marck Athias, Introdução do Método Experimental e suas Principais Aplicações às Ciências Médicas e Biológicas em Portugal (Coimbra, 1940).

38 Marck Athias; Castro Ramos, 'Os meios de Luta contra o Cancro em alguns Países Europeus', Arquivo de Patologia, 2 (1930), 4-13.

39 Marck Athias, 'Cytologia do Cancro (resumo)', Medicina Contemporânea, 25 (1907), 165-68; Marck Athias, 'Cytologia Geral do Cancro ', Jornal da Sociedade de Sciencias Médicas de Lisboa, 72 (1908), 11042; Marck Athias, 'O Problema do Cancro na Conferência Internacional de Londres', Medicina Contemporânea , 47 (1929), 79-89; Marck Athias, 'Organisation de la Lutte contre le Cancer au Portugal', Arquino de Patologia , 6 (1934), 539-51; Marck Athias, 'Organisation de la Lutte contre le Cancer', 4, [2], [3] (1937); Marck Athias, 'Os recentes Progressos no Estudo Experimental do Cancro', Medicina, 27 (1937), 1-13, Marck Athias, 'Hipóteses sobre as Causas do Cancro', Boletim Instituto Português de Oncologia , 4, [6] (1937), 2-3; Marck Athias, 'A luta Social contra o Cancro e o Valor das Estatísticas', Boletim Instituto Português de Oncologia, 4 (1937), 10-12; Marck Athias, 'Posição actual do Instituto Português de Oncologia', Boletim Instituto Português de Oncologia, 5 (1938), 1-3; Marck Athias, 'Hipóteses sobre a Origem do Cancro', Boletim Instituto Português de Oncologia, 5 (1938), 4-5; Marck Athias, 'Cancro', Grande Enciclopédia Portuguesa e Brasileira, Marck Athias, O problema do Cancro (Lisbon, 1941); and, Marck Athias, 'O Instituto Português de Oncologia em 1940 e 1941', Medicina Contemporânea, 61 (1943), 17-25.

${ }^{40}$ Marck Athias, 'O Tratamento Anti-Rábico no Real Instituto Bacteriológico Câmara Pestana em 1905', Archivos do Real Instituto Bacteriológico Câmara Pestana, 1 (1907), 177-86; Marck Athias, 'O Tratamento Anti-Rábico no Real Instituto Bacteriológico Câmara Pestana em 1906', Archivos do Real Instituto Bacteriológico Câmara Pestana, 2 (1909), 63-71; Marck Athias, 'O Tratamento Anti-Rábico no Real Instituto Bacteriológico Câmara Pestana em 1907’, Archivos do Real Instituto Bacteriológico Câmara Pestana, 2 (1909), 369-76; Marck Athias, 'Le Traitement Antirabique à L'Institut de Bacteriologie Câmara Pestana en 1908', Archivos do Real Instituto Bacteriológico Câmara Pestana, 3 (1910), 45-57; Marck Athias, 'Le Traitement Antirabique à L'Institut de Bacteriologie Câmara Pestana en 1909', Archivos do Real Instituto Bacteriológico Câmara Pestana, 3 (1912), 373-78; Marck Athias', Le Traitement Antirabique à L'Institut de Bacteriologie Câmara Pestana en 1910-1911', Archivos do Real Instituto Bacteriológico Câmara Pestana, 4 (1916), 41 -56; Marck Athias, 'Le Traitement Antirabique à L'Institut de Bacteriologie Câmara Pestana en 1912', Archivos do Real Instituto Bacteriológico Câmara Pestana, 4 (1916), 173-78; Marck Athias and Pereira da Silva, 'Le Traitement Antirabique à L'Institut de Bacteriologie Câmara Pestana en 1913-1914', Archivos do Real Instituto Bacteriológico Câmara Pestana, 5 (1918), 89-99; Marck Athias, Actividade Científica, Relatório Administrativo (Lisbon, 1938).

41 Topics covered included: the experimental study of hermaphroditism in higher animals; the heart's automatisms, pathologies and regulatory mechanisms; hibernation in mammals; diencephalic centres of vegetative life; current issues in endocrinology; sex hormones and their pathophysiological effects; the fiftieth anniversary of the neuron theory, and the neurophysiology of the synapse. 


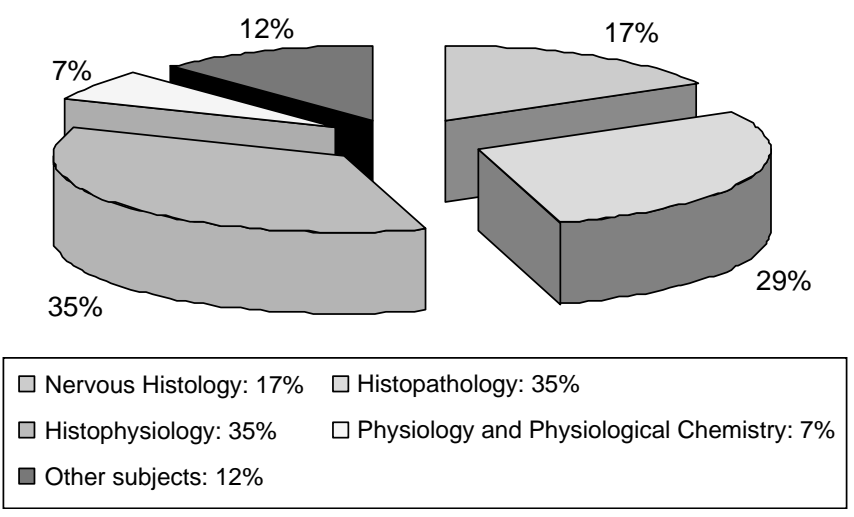

Figure 2. Research areas covered in Marck Athias's scientific papers published between 1895 and 1946.

The scientific papers represent Athias's major contribution to science and span the different areas on which his research school focused: histology, histophysiology, histopathology, physiology, and physiological chemistry, as shown in Figure 2.

Besides publishing papers in core areas, Athias also published several papers on cytology, parasitology, and morphology. The figure shows Athias's particular interest in the histology of the nervous system, in histopathology and histophysiology. This trend reflects the direction taken by Athias and his school, the decisions they made collectively over time, and the particular circumstances that surrounded their research work at the institutions that employed them as lecturers and researchers. Athias's work on the histology of the nervous system was interrupted on his return to Portugal and by his gradual separation from Mathias Duval's laboratories, where he had originally carried out research. Another important factor that led Athias to discontinue this line of research were requests for collaboration from the Medical School of Surgery, the Câmara Pestana Bacteriological Institute and the Institute Pasteur of Lisbon. These requests forced him to work simultaneously in different scientific domains, leaving him hardly any time to pursue his investigations into the histology of the nervous system. From 1906, such requests determined his scientific career. The subject to which he contributed most significantly was histophysiology, because it was the one that brought together the two scientific fields he knew best. It was also the one that attracted the largest number of disciples and had the best conditions for its development. In this specialty, his first paper on secretion phenomena of the true lutean bodies $(1906)^{42}$ used experimental data obtained at the histology laboratory of the Medical School of Surgery. Athias's last paper on the histology of the nervous system was published in $1942^{43}$ and was based on research carried out at the laboratory for experimental pathology of the Portuguese Institute of Oncology. In a sense, this paper represents the end of a cycle, which was probably what Athias had in mind. The idea of studying internal secretions from histological and physiological perspective and relating them to cancer was most likely the starting

\footnotetext{
42 Marck Athias, 'Sur les Phénomènes de Sécrétion des Cellules des Corps Jaunes Vrais', XV Congrès Internationale de Médecine de Lisbonne, Section I (Lisbon, 1906).

43 Marck Athias, 'Secreções Internas e Cancro', Medicina Contemporânea, 9 (1942) (separata), 1-7.
} 
point for the emergence of experimental and clinical endocrinology in Portugal. The papers on topics in physiology and physiological chemistry are the lesser part of his scientific publications for the above-mentioned reasons: Athias was mainly interested in associating physiology with histology and in using different histophysiological methods to investigate a whole range of issues.

Athias published mainly in Portuguese journals, but he wrote his papers in both French and Portuguese. This shows his concern with making Portuguese science known abroad, but also with reaching out to the Portuguese scientific community, at both a more specialized and a more general level. Athias was determined to create regular publishing habits within the Portuguese medical community and also to make Portuguese science known to the international scientific community.

Athias's scientific publications clearly reflect his research career, with a gradual broadening of scientific domains and his attempts at disciplinary colonization. They also show the close relationship that he developed with the institutions where he implemented his research school's programme. In order to strengthen the dissemination and expansion of the programme, Athias and some of his disciples founded and edited specialist journals in their own fields of research: Comptes Rendus de la Société de Biologie de Paris, Bulletin de La Société Portugaise des Sciences Naturelles, Archives Portugaises des Sciences Biologiques, and Politechnia.

\section{The disciples}

Marck Athias's research school included two types of followers: his disciples as such, and his co-workers. The disciples were all those who began their scientific careers in the laboratories run by Athias, regardless of whether they pursued a scientific career later on. The co-workers were those who made use of whatever knowledge they had acquired from Athias at his laboratories of histology, physiology, histopathology, or physiological chemistry but developed their scientific careers independently. With this classification in mind, forty-two disciples and four coworkers were identified.

The study of the disciples' relationships with Athias, with their colleagues, and with society in general was based on a survey of all the members of his school. ${ }^{44}$ Several parameters were considered: time spent in Athias's laboratories, the research domains chosen by individual scientists, the type of scientific research undertaken, their involvement in scientific institutions, their status in the various journals used by the school to disseminate its programme, their professional careers, and any prizes or awards.

Based on an analysis of these data, Athias's disciples can be divided into three groups. There were those who were part of the 'central core' of the research school with respect to its major lines of research: histology, histophysiology, histopathology, physiology, and physiological chemistry. These disciples remained associated with Athias for longer periods, regardless of whether they were in direct contact with him at the various laboratories where he worked. Then, there was the group who were trained along the major lines of research at Athias's research school and later used them in other faculties or institutions. Finally, there was the group of those for whom the laboratories of the research school were merely a temporary stage in their careers.

44 Amaral, op. cit. (16), pp. 288-97. 
The disciples belonging to the central core were trained at the various laboratories where the school's research programme was pursued: the histology laboratories at Rilhafoles Hospital (Hospital de Rilhafoles - GHHR), the Medical School of Surgery (LHEMC), the Câmara Pestana Bacteriological Institute (IBCP), the Institute of Physiology of the Faculty of Medicine (IFFM), and the laboratory for histology and experimental pathology of the Portuguese Institute of Oncology. This central core included Celestino da Costa, Ferreira de Mira, Joaquim Fontes, Jacinto Moniz de Bettencourt, Henrique Parreira, and Maria Teresa Furtado Dias. Celestino da Costa pursued his research in normal histology and eventually created another research school on histology and embryology at the Faculty of Medicine of Lisbon. ${ }^{45}$ Ferreira de Mira, Joaquim Fontes, and Jacinto Moniz de Bettencourt pursued the research programme in histophysiology, physiology, and physiological chemistry at the Institute of Physiology of the Faculty of Medicine. Finally, Henrique Parreira ${ }^{46}$ and Maria Teresa Furtado Dias applied the histopathology programme to oncology at the Portuguese Institute of Oncology (IPO). Parreira's collaboration with Athias at the IPO was of paramount importance for their school in the field of cancer research, as it was with this disciple that Athias conceived and planned the Institute. Besides, the school's research programme was to become consolidated in the field of cancer research through Parreira's scientific work. Maria Teresa Furtado Dias was Marck Athias's sole female disciple. Her inclusion reflects Athias's open-mindedness regarding the involvement of women in scientific research, as well as the courage of a woman who, despite unfavourable circumstances, was to become Athias's 'right hand' at IPO's laboratory for experimental pathology. ${ }^{47}$ Table 1 lists this group of disciples as well as their scientific output during the periods when they were associated with Athias.

From a very early stage, Marck Athias's research school was keen to establish its own communication channels. The aim was twofold: to disseminate its own scientific work and to control national scientific output in the scientific fields it wished to influence. The research school was able to effectively control such output through the editing of journals, as it was up to the editors to decide the standards and criteria for the submission of papers for publication. At the same time, editorial responsibilities provided a vantage point from which to oversee what was being produced by the scientific community. The journals were published under the aegis of scientific societies to which the research school contributed significantly. Table 2 provides a summary of the central core's role in the dissemination and control of national scientific production.

Marck Athias, Celestino da Costa, and Abel Salazar were the founders of two learned societies, the Portuguese Society of Natural Sciences (Sociedade Portuguesa de Ciencias Naturais) in 1907, and the Portuguese Society of Biology (Sociedade Portuguesa de Biologia) in 1920. The first society published Bulletin et Mémoires de la Société das Sciences Naturelles, Jornal das Ciencias Naturais, and Naturalia. The second published Archives Portugaises des Sciences Biologiques. ${ }^{48}$ Furthermore, the

\footnotetext{
45 Isabel Amaral, José David-Ferreira, Ruy E. Pinto, and Ana Carneiro, 'A Escola de Histofisiologia de Augusto Celestino da Costa (1911-1956)', Actas do $1^{\circ}$ Congresso Luso-Brasileiro de História da Ciência e da Técnica (2001), 615-629.

46 Marck Athias, 'Henrique Parreira (1895-1945)', Arquivo de Patologia, 17 (1945), 1-18.

47 Augusto Celestino da Costa, 'Athias e a Investigação Científica', Cadernos Científicos (separata), 3 (1946), 253.

${ }^{48}$ This journal of Sociedade Portuguesa de Biologia was founded in 1920 and edited jointly by Marck Athias, Abel Salazar, and Augusto Celestino da Costa.
} 
Table 1. Central core of disciples at Marck Athias's research school and their scientific contributions ${ }^{\mathrm{a}}$.

\begin{tabular}{|c|c|c|c|}
\hline Disciples & $\begin{array}{c}\text { Time spent at Athias's } \\
\text { laboratories }\end{array}$ & $\begin{array}{l}\text { Research } \\
\text { areas }\end{array}$ & $\begin{array}{l}\text { Scientific papers and } \\
\text { teaching materials }\end{array}$ \\
\hline $\begin{array}{l}\text { Celestino da } \\
\text { Costa }(1884-1956)\end{array}$ & $\begin{array}{l}\text { GHHR/ IBCP/LHEMC/IHFM } \\
(1898-1911)\end{array}$ & Histology & 19 \\
\hline $\begin{array}{l}\text { Ferreira de de } \\
\text { Mira }(1875-1952)\end{array}$ & $\begin{array}{l}\text { IFFM (1911-1945), IRC } \\
(1925-1946)\end{array}$ & Physiology & 70 \\
\hline $\begin{array}{l}\text { Joaquim Fontes } \\
(1892-1960)\end{array}$ & IFFM (1918-1946) & Physiology & $\begin{array}{l}2 \text { textbooks } \\
85\end{array}$ \\
\hline $\begin{array}{l}\text { J. Moniz de } \\
\text { Bettencourt (1905- }\end{array}$ & IFFM (1935-1946) & Physiology & 12 \\
\hline $\begin{array}{l}\text { Henrique Parreira } \\
(1885-1945)\end{array}$ & $\begin{array}{l}\text { IBCP }(1907-1908), \text { IFFM } \\
(1908-1911), \text { IPO }(1923-1945)\end{array}$ & Histology & 43 \\
\hline $\begin{array}{l}\text { M. Teresa Furtado } \\
\text { Dias }\end{array}$ & IPO $(1932-1946)$ & $\begin{array}{l}\text { Pathological } \\
\text { histology }\end{array}$ & 19 \\
\hline
\end{tabular}

Note:

aHEFM: Institute of Hystology and Embryology of the Faculty of Medicine (Instituto de Histologia e Embrilogia da Faculdade de Medicina de Lisboa).

research school also published Politechnia and Archives of Pathology (Arquivo de Patologia). ${ }^{49}$ Papers were published preferentially in French, reflecting both a willingness to internationalize Portuguese biomedical sciences and the legacy of the French scientific tradition which left a very significant imprint on Athias and his followers.

In addition to their involvement in the activities of the learned societies they controlled, the members of the research school were also keen to edit the journals of such societies and of the research institutes that they led. The journal Politechnia was edited by Celestino da Costa and Henrique Parreira; Boletim da Sociedade de Ciências Naturais and Naturalia by Celestino da Costa; and Archives Portugaises des Sciences Biologiques by Celestino da Costa and Jacinto Moniz de Bettencourt. Together with other journals such as Travaux de l'Institut de Physiologie from Lisbon and Oporto, Travaux de l'Institut d'Histologie et Embriologie, and Travaux de Laboratoire from the IRC, they represent the whole range of publications stemming from the institutions into which Athias's research programme expanded. This, too, reflects the notion of the research school as a continuum, a feature it shared with foreign institutions. In addition, to these specialized journals from different laboratories or institutes into which some of the laboratories gradually grew, there was also the Boletim of the IPO, edited by M. Teresa Furtado Dias.

The members of Athias's school not only became involved in the learned societies that served to disseminate its research programme but also took part in the activities of foreign scientific societies, particularly French ones, that covered the range of specialties included in the programme: Association des Anatomistes, Association des Physiologistes, Société de Chimie Biologique, and Association Française pour l'Étude $d u$ Cancer. They also made a point of setting up Portuguese equivalents to such institutions: the Portuguese Association of Anatomy (Associação Anatómica

49 F. Namora, Luis Botelho, and Francisco Gentil (1878-1964) (Lisbon, 1946). 
Table 2. Editorial activities of the central core of disciples at Marck Athias's research school.

\begin{tabular}{|c|c|c|c|}
\hline Disciples & Editorial activities & Posts held in scientific societies & Public posts held \\
\hline \multirow[t]{5}{*}{$\begin{array}{l}\text { Celestino da Costa } \\
(1884-1956)\end{array}$} & \multirow{5}{*}{$\begin{array}{l}\text { Founder and editor of } \\
\text { Travaux de l'Institut } \\
\text { d'Histologie } \\
\text { et Embriologie FMUL }\end{array}$} & $\begin{array}{l}\text { Chairman-Section of Sciences of the } \\
\text { Academia das Ciências de Lisboa }\end{array}$ & Prof. of Histology at FMUL \\
\hline & & Member of Association des & Chairman of Committee for National \\
\hline & & Founding member of Sociedade & Director of Centro de Investigação de \\
\hline & & Portuguesa de Endocrinologia & $\begin{array}{l}\text { Histologia e Embriologia of the } \\
\text { Institute for High Culture }\end{array}$ \\
\hline & & $\begin{array}{l}\text { Founding member of the Sociedade } \\
\text { Luso-Espanhola de Endocrinologia }\end{array}$ & \\
\hline \multirow{3}{*}{$\begin{array}{l}\text { Ferreira de Mira } \\
(1875-1952)\end{array}$} & \multirow{3}{*}{$\begin{array}{l}\text { Founder and editor of } \\
\text { Travaux } \\
\text { de Laboratoire, IRC Editor, } \\
\text { Actualidades Biológicas }\end{array}$} & $\begin{array}{l}\text { Member of Soc. Estudos Pedagógicos } \\
\text { da Société de Chimie }\end{array}$ & City Councillor in Lisbon \\
\hline & & Biologique de Paris & $\begin{array}{l}\text { Prof. of Physiological Chemistry at } \\
\text { FMUL }\end{array}$ \\
\hline & & $\begin{array}{l}\text { Member of Association des } \\
\text { Physiologistes, Paris }\end{array}$ & Director of IRC (1925-1952) \\
\hline \multirow{2}{*}{$\begin{array}{l}\text { Joaquim Fontes } \\
(1892-1960)\end{array}$} & & Chairman of Association des & Director of IRC (1952-) \\
\hline & & Physiologistes & \\
\hline \multirow{6}{*}{$\begin{array}{l}\text { J. Moniz de } \\
\text { Bettencourt } \\
(1905-)\end{array}$} & \multirow{6}{*}{$\begin{array}{l}\text { Editor-in-chief; Member of } \\
\text { the Editorial Board of Jornal } \\
\text { da Sociedade de Ciências } \\
\text { Médicas de Lisboa }\end{array}$} & Vice-Chairman of Sociedade & Prof. of Physiology at FMUL \\
\hline & & Portuguesa de Cardiologia & \\
\hline & & Member of Sociedade de Medicina Interna & Researcher at IRC \\
\hline & & $\begin{array}{l}\text { Member of Sociedade Portuguesa de } \\
\text { Endocrinologia }\end{array}$ & \\
\hline & & Corresponding Memmber of Société & \\
\hline & & Française de Cardiologie & \\
\hline
\end{tabular}


Table 2 (Continued).

\begin{tabular}{|c|c|c|c|}
\hline Disciples & Editorial activities & Posts held in scientific societies & Public posts held \\
\hline $\begin{array}{l}\text { Henrique Parreira } \\
(1885-1945)\end{array}$ & $\begin{array}{l}\text { Editor-in-chief Arquivo de } \\
\text { Patologia }\end{array}$ & $\begin{array}{l}\text { Corresponding Member of Association Française } \\
\text { pour l'étude du Cancer } \\
\text { Member of Association des Anatomistes, Paris } \\
\text { Member of Associação dos Arqueólogos Portugueses }\end{array}$ & $\begin{array}{l}\text { Chairman of Instituto de Anatomia } \\
\text { Patologica, FMUL } \\
\text { Member of the Board at IPO } \\
\text { Head of the Dept. of Pathological } \\
\text { Anatomy IPO }\end{array}$ \\
\hline $\begin{array}{l}\text { M. Teresa Furtado Dias } \\
\text { (?) }\end{array}$ & $\begin{array}{l}\text { Editor of Boletim do IPO, } \\
\text { Arquivo de } \\
\text { Patologia and Clínica } \\
\text { Contemporânea }\end{array}$ & $?$ & $\begin{array}{l}\text { Director of the Laboratory of } \\
\text { Experimental Pathology at IPO }\end{array}$ \\
\hline
\end{tabular}


Portuguesa), the Portuguese Society of Endocrinology (Sociedade Portuguesa de Endocrinologia), and the Spanish Lusitanian Society of Endocrinology (Sociedade Luso-Espanhola de Endocrinologia).

Athias's disciples opted for teaching or research careers not only in the research school's specialties but also in other scientific fields. This shows that the research programme of Athias's school had the ability to 'migrate' to 'new areas of ignorance', thus leading to the development of new disciplines. ${ }^{50}$ However, as Table 2 clearly shows, positions in histology, physiology, and physiological chemistry tended to predominate, especially in university teaching careers, a fact that supports the notion that the research school evolved towards disciplinary consolidation.

From this set of data, it is possible to conclude that Marck Athias greatly influenced the Portuguese scientific community of his time, clearly espousing a research model in which experimental work played a fundamental role.

\section{The laboratories}

Marck Athias's research school worked in several laboratories that either already existed or were founded and directed by Athias or his disciples. Between 1897 and 1903, the school's research programme was pursued simultaneously in the histology laboratories of the Hospital of Rilhafoles and Câmara Pestana Bacteriological Institute; between 1903 and 1906, in the histology laboratories of Câmara Pestana's Bacteriological Institute and the Medical School of Surgery; between 1929 and 1946, in two physiology laboratories - those of the Faculty of Medicine of Lisbon and the IRC, and, after 1923, in the laboratory for experimental pathology of the Portuguese Institute of Oncology.

The laboratory at the Hospital of Rilhafoles, to which many of Athias's disciples flocked, was considered unsatisfactory for practical work in histology, as it had grown out of a refurbished office in 1897. It was eventually closed down in 1903 by the Head Nurse of Civilian Hospitals, allegedly for economic reasons. The existing laboratory equipment was inadequate and out of date. ${ }^{51}$ The most advanced microscope available was a Vérick-Stiassnie that belonged to Athias. The remaining laboratory equipment was considered very basic, and there was no library.

Conditions at the laboratory of the Medical School of Surgery were not significantly better. The laboratory was considered by Athias, Celestino da Costa and Joaquim Fontes ${ }^{52}$ as 'absolutely inadequate ${ }^{53}$ for research work. Athias and his disciples left some descriptions of the facilities. It was apparently a rather small room, measuring some $8.8 \mathrm{~m}$ by $3.5 \mathrm{~m}$, and with only one window. This suggests that lighting was poor and that observing histological preparations under the microscope was most likely a difficult task. There were four desks in the laboratory, of which the one closest to the window was Athias's, and the others were used by his students and

${ }^{50}$ Gerald L. Geison, 'Scientific Change, Emerging Specialties, and Research Schools', History of Science, 19 (1981), 29

51 According to Celestino da Costa, 'we had a single microscope, an old Nachet with manual focus, no immersion, no screw, an inadequate microtome and so on' Augusto Celestino da Costa, op. cit. (46), 24962. 9

52 Joaquim Fontes, 'Marck Athias, Fisiologista', Clinica, Higiene e Hidrologia (separata), 13 (1947), 1-

${ }^{53}$ Marck Athias, 'O Ensino da Fisiologia na Régia Escola de Cirurgia e na Escola Médico-Cirúrgica de Lisboa', Clínica Contemporânea, 6 (1946), 338. 
co-workers. Physical access to the facilities was difficult, and the laboratory did not have its own library. The only one available was the general library of the Medical School of Surgery. In order to gain access to this library, as well as to the laboratory, Athias and his co-workers had to go through the museum of anatomy, where physiology classes were held. The laboratory equipment included a Zeiss microscope that Miguel Bombarda had been able to purchase with funds made available for his own course. However, reagents, animals for experiments, and other sundries had to be purchased and paid for by the students and co-workers themselves.

Subscriptions to journals such as Journal d'Anatomie, Anatomischer Anzeiger, and Archiv für mikroskopische Anatomie were paid for by the institution, but whenever a book or other important publication had to be purchased, it was up to those interested in it to cover the costs. ${ }^{54}$ It was not easy for young doctors to engage in scientific research, at a time when medical schools had yet to acknowledge that research was the decisive element for the development of Portuguese medicine. Furthermore, researchers were not paid for their work and had to buy their own reagents, animals, laboratory equipment, and often their own books and journals. In 1948, Celestino da Costa described this period at the Medical School of Surgery in the following terms: 'Those who work in our laboratories today cannot imagine the difficulties and the hardships we faced in those heroic days' ${ }^{55}$ The commitment to which Celestino da Costa alludes should be seen against the backdrop of Marck Athias's attitude, which was followed by all his disciples and many of his contemporaries: the notion of an almost heroic commitment requiring self-sacrifice for the advancement of science.

Athias's transfer to the physiology laboratory at the Faculty of Medicine of Lisbon, which became an Institute in 1911, was seen as an opportunity to improve existing working conditions, not only from the viewpoint of logistics, but also in terms of the laboratory equipment. In 1909, Athias and one of his disciples visited various European countries to learn about the teaching of histology in foreign universities and also to find out about the organization of scientific research. ${ }^{56}$ With the funds that were made available to him, Athias purchased crucial and more stateof-the-art equipment, and subscribed to major specialist journals which he endowed to the libraries at both the Institute of Physiology and Histology of the Lisbon Faculty of Medicine after 1911.

Their tour had profound effects. Athias became aware of different ways of organizing scientific research, in physiology in particular. He also became familiar with many aspects of such disciplines: practical teaching, essential laboratory equipment, and the manufacturers of the most sophisticated and up-to-date equipment. In theory, Athias had all the necessary prerequisites to successfully engage in scientific research in his chosen fields, for Miguel Bombarda's views on experimental teaching and scientific research had created the mindset to embrace the new guiding principles and practices of experimental medicine.

\footnotetext{
54 Augusto Celestino da Costa, O Ensino Médico em Lisboa-a Histologia e a Embriologia (Lisbon, 1925).

55 Augusto Celestino da Costa, op. cit. (33), 153.

56 Funding for the tour was secured by Athias's patron, Miguel Bombarda, who negotiated with the government for a loan of 110 contos (550 euros) for the establishment of the 'new medical school' they both longed for. Augusto Celestino da Costa, 'A vida e Obra Científica de Marck Athias', Arquivo de Anatomia e Antropologia, 26 (1948), 153.
} 
The faculty's premises were built between 1891 and 1906, but they were designed for a much smaller student population than that actually enrolled after 1911. This fact shows the State's inability to look ahead when planning and designing such buildings. When the building finally opened, some twenty years later, it did not meet the requirements of a growing number of students. In addition, the designers had little or no idea of the facilities that were required for scientific research. Athias tried to overcome some of these drawbacks, but there were some aspects about which he could do nothing. This episode reflected the absence of a scientific tradition geared towards experimentation, and the absence of a culture encouraging collaboration between scientists and architects, which arose in other European countries throughout the nineteenth century. From such collaboration resulted buildings that were designed to house research laboratories and that remained functional for several decades.

There are no descriptions of the working conditions at IFFML. However, favourable opinions were expressed about other institutes within the same faculty such as the IHEFM. Some of Athias's disciples described them as very good, and it is reasonable to assume that conditions were similar in the physiology laboratory: the rooms were spacious and well equipped. ${ }^{57}$ The greatest obstacle was the lack of adequate facilities to house animals for experiments. There was only one facility in the faculty that had to be shared by all departments. It was located in another wing of the building, away from the laboratories used by Athias's and Celestino da Costa's research schools, which made the supply and use of animals a major difficulty. Unsuccessful attempts were made to set up new facilities equipped with aseptic operating rooms next to the research institutes. ${ }^{58}$ This failure led to the transfer to the IRC of some of the research work after 1927, particularly experiments associated with physiology. The problems in the faculty were in this way overcome at IHEFM and at IRC. Compared with other Portuguese laboratories, working conditions at these two institutions were significantly better.

The last laboratory where Marck Athias's research school worked was the laboratory for experimental pathology established in 1933 by Francisco Gentil, then director of the Portuguese Institute of Oncology. The histology and experimental laboratories were temporarily housed in the first building to constructed in 1933known as the radium building - but they were spacious enough. ${ }^{59}$ Nevertheless, conditions regarding equipment, materials, reagents, and availability of experimental animals were far superior to anything Athias had known before.

The working conditions at this institution differed significantly from those of other laboratories where Athias's school had previously carried out its research programme. Because IPO was a specialized hospital, and had protection from the State and the support of many volunteers, its budget was distinct from that of other university hospitals at the same time. Because this institution was based in a hospital,

57 Celestino da Costa, in his book on the teaching of histology at Instituto de Histologia e Embriologia, of which he became the director in 1911, describes the development of the histology laboratory at The Medical School of Surgery between 1906 and 1911, as well as the research carried out since 1898 under Athias in the many laboratories where he had disciples. He describes the laboratory thus: 'The laboratory at the Institute... had conditions that were unique in our country. New and abundant materials, a wellstocked library with many specialist journals and subscriptions, as well as the most recent books, spacious rooms in stark contrast with the sordid facilities at the old school'. Augusto Celestino da Costa, O Ensino Médico em Lisboa - a Histologia e a Embriologia (Lisbon, 1925).

58 Augusto Celestino da Costa, op. cit. (46), 258.

59 Ibid. 
its researchers were not engaged in teaching and could work full time in the laboratories under more stable working conditions. Despite the small number of researchers involved, its research output was significant. There was a good working atmosphere characterized by a strong esprit de corps reinforced by the personal ties among its directors. The same atmosphere prevailed in other IPO departments, including that of Athias where the institute's research was actually carried out.

Various factors explain the number of laboratories where the research school implemented its research programme: on the one hand, as Athias held positions in different institutions, he took with him some of his disciples, thus winning over new facilities for new scientific specialties; on the other hand, commitment to producing quality research was only possible if certain logistic, financial, and material conditions were met. As few laboratories met these requirements, there was a need for researchers to move between them.

\section{The research programme}

Marck Athias's research programme comprised several separate research lines that sometimes overlapped or complemented one another (histology of the nervous system, histophysiology, histopathology, physiology, physiological chemistry) and were developed in several laboratories and institutions.

Research was initially undertaken in 1897 on the histophysiology of the nervous system, a field to which Athias had first contributed in 1895, and this activity lasted until 1915. From 1905 on, the research programme was broadened to include general histophysiology, and from 1911 onwards it diversified into physiology and physiological chemistry, and after 1923 into histopathology. These were the specialties that colonized well-established medical disciplines whose traditions went back centuries.

As regards the histology of the nervous system, Athias's school focused its attention on neural development and cellular infiltrations in the brain. In histophysiology, the school investigated the mechanisms of endocrine glands. Physiological research looked into the physiology of muscles, glands, and organs such as the kidney and the heart. In physiological chemistry, Athias's school looked for chemical explanations for the physiological phenomena that were being studied. Finally, in histopathology, the school engaged in oncological studies that involved inducing tumours in selected strains of mice.

The research programme was essentially based on experimentation and the study of living organisms, from normal to pathological states, and was inspired by causeeffect theories. It relied on the application of histology to physiological studies, as was to be expected at a time when biology was moving from an organ-based approach to a cell-based approach. However, physiological chemistry was already moving from the cellular to the molecular level. Furthermore, the methodology and the imaging techniques used by Athias's research school were similar to the methods of Ramón y Cajal, in particular for the nervous system.

The laboratories directed by Athias became prestigious research centres for the abovementioned biological and biomedical specialties due to the importance of the work produced and the volume of research carried out by his students. Looking at the school's scientific production, it is clear that throughout the different periods and regardless of the laboratories where its members worked, their research interests covered a variety of subjects. This too reflects the agenda behind Athias's research 
school: a school that would take under its wing the various biomedical specialities emerging within already-established disciplines.

The school's research programme naturally remained true to its leader's specialty, histology, and was generally geared towards the application of morphological methods to physiological studies, in particular in histophysiology and histopathology. This explains why most of Athias's disciples eventually took up key university positions in physiology, histology, and normal and pathological anatomy. Besides physiology, the school's research programme also covered physiological chemistry under Ferreira de Mira, who extended the programme beyond the Faculty of Medicine of Lisbon and continued it at the IRC from 1929 onwards, at the IFFM after 1935, and at the Faculty of Medicine of Oporto from 1926 onwards.

The various research lines of Athias's school that are briefly sketched above ${ }^{60}$ suggest that Athias and his disciples were looking for explanations regarding the functioning of organs, glands, and tissues based on the notion of 'internal secretion'. In the case of the testicles, ovaries, and heart, for example, this approach found an echo in later developments that were of paramount importance to the establishment of endocrinology in Portugal during the second half of the twentieth century.

\section{The school's role in the scientific community and in society: Ideology and practice}

In addition to its impact on Portuguese biomedical research, Marck Athias's research school also played an important social and political role. Some of its members held public positions, especially in science, and became involved in many activities within the Portuguese scientific community aimed at controlling and fostering learned societies and journals, as well as promoting within and outside the scientific community a specific model of university education and scientific research.

\subsection{Science ideology and 'propaganda'}

All such activities were based on a series of ideological assumptions that are worth discussing. These assumptions and ideological commitments are usually factors that promote cohesion between members of a group, as these kinds of affinities tend to strengthen the members' esprit de corps and serve as a backdrop against which their activities are undertaken.

The more policy-oriented texts that came out of Athias's school-articles by Santiago Ramón y Cajal; texts by Athias and Celestino da Costa paying homage to Cajal, an individual the school considered exemplary; texts praising Marck Athias written by his disciples, and even more doctrinaire texts by Celestino da Costa and Ferreira de Mira - show that besides its significant contributions to science, the group also had an agenda for the scientific community and for Portuguese society at large.

Many of the above-mentioned texts have a positivist slant, although no explicit reference to Auguste Comte is to be found in any of them. This is not surprising, as Portuguese republican ideology, of which Teófilo Braga (1843-1924) ${ }^{61}$ was a leading figure, was strongly influenced by positivism via Littré.

\footnotetext{
${ }^{60}$ For a detailed study of the research lines that made up the school's research programme, see Isabel Amaral, op. cit. (16), pp. 112-34.

61 Teófilo Braga graduated in law from Coimbra University. As a politician, he was a herald of republicanism. He became a member of the Republican Party and was President of the First Republic. He is also known as a distinguished poet and positivist historian of Portuguese culture.
} 
Cajal's scientific achievements in physiology, bacteriology, and histology were considered by Athias and his disciples as one of the foremost examples of experimental method in use, with Cajal's emphasis on observation and scientific facts, experimentation, and laboratory techniques. They were also a reminder of the need to promote scientific production in quantitative and qualitative terms, and reflected a boundless confidence in the powers of science, while stressing its benefits and praising self-sacrifice and self-denial for the sake of the progress of mankind.

Such moral and patriotic values associated with science were ultimately responsible for Cajal and Athias's social and political commitments, although the latter did not play a direct part in politics. His disciples Celestino da Costa and Ferreira de Mira were the most obvious followers of such principles, reflected in their devotion to science as a means of extolling the nation's virtues. The two took these principles from the laboratories into the public and political spheres. It was therefore natural that such values should be brought to the fore at a ceremony in honour of Cajal, which took place in 1913, as political engagement was viewed as a moral imperative and patriotic duty for every scientist ${ }^{62}$ :

The magnificent work of Rámon y Cajal is the best example of what a tenacious researcher can achieve ... when he is inspired by the eager desire to elevate his country, by developing a science that did not exist in it before. The patriotic spirit of Cajal suffered a blow with his country's tragedy ... he was hesitant but his friends and the government asked him not to reject the invitation.

At the ceremony, particular stress was put on Cajal's role (and hence on Athias's) in the emergence of new specialties, particularly those that Athias's school pioneered in Portugal - physiology, histophysiology, histopathology, and physiological chemistry. The idea of establishing a school and of training followers was also emphasized. The extent to which a school's programme and its works became disseminated was said to be measured by the number of scientific publications, which should ideally be large. In those publications, experimental facts and conclusions should be described in detail. All these features were part of the principles underlying Athias's school and relevant traits in Cajal's work. The example of Cajal was thus put forward as a model and as a legitimizing authority for Athias's school: 'More than three hundred papers and books, a large number of disciples in many countries and, above all, his [Cajal's] personal contributions to the advancement of the biological sciences prove that he accomplished the programme he had originally set himself' ${ }^{63}$

Cajal's work was also adopted as a model for other aspects of the Athias school's activities, in particular the imaging techniques used to make objects under investigation visible and thus bestow on them the status of scientific facts. It should be noted that, at the time, the use of photography and drawings to depict experimental observations was considered the most appropriate way to make indisputable observations and ascribe credibility to one's interpretation of experimental results. Both Cajal and Marck Athias and his disciples were committed to rigorously reproducing their observations. They all used microphotography and scientific drawings to effectively depict the data of a science they viewed as a positive endeavour. The use of such techniques is one of the innovative aspects of Athias's

\footnotetext{
${ }^{62}$ Marck Athias, 'Santiago Ramón y Cajal', Lisboa Médica, 11 (1913), pp. 6 and 18.

63 Ibid., p. 6.
} 
school, which produced the first textbooks containing original illustrations published in Portugal.

There are obvious similarities between the work of Cajal and that of Athias, as well as between the peripheral contexts in which they worked, despite the different impact they had on the international scene. The lack of acknowledgement for Cajal's neuron theory because it had been proposed by a scientist from a peripheral country like Spain is echoed in the general unfamiliarity with Athias's work, which went unnoticed in the international scientific community despite references in Testut's treaty on anatomy ${ }^{64}$ and Athias's effort to publish his papers in French. Since both Iberian nations lacked a scientific tradition that could draw the attention of foreign scientists by itself, their work would most likely pass unnoticed unless they could overcome the language barrier.

In Marck Athias's research school, ethos and rhetoric were strongly inspired by positivism because of Athias's contact with French culture and the influence of Cajal. However, its scientific practice was modelled on the German tradition. This reflects the debates in Europe on the alleged decline of French science and Germany's scientific superiority, which erupted in the aftermath of the Franco-Prussian war and extended well into World War I. ${ }^{65}$ Athias had become interested in these debates in France. However, he sided with those in France and elsewhere who, although disagreeing with German imperialist actions, considered the German university system the best worth imitating. In addition, Athias's most preeminent disciples, Celestino da Costa and Ferreira de Mira, had cultural contacts with Germany through relatives and friends who studied in German institutions both scientific and artistic. All these factors contributed to the modelling of Athias's school on the German example.

Celestino da Costa and Ferreira de Mira were the two disciples of Athias who best exemplify the debates about German science taking place in Europe at the time. Their ideas on the organization of universities and the role of scientific research were undoubtedly influenced by the fact that Athias had been a student at the Faculty of Medicine in Paris ${ }^{66}$ at a time when there were heated debates about the superiority of German universities and research. Indeed, Athias had witnessed the discussions in the French scientific community during the second half of the nineteenth century dominated by waves of religious fervour and doubt, nationalism, and internationalism. Celestino da Costa and Ferreira de Mira's approach was strongly influenced by Athias but quite unique in Portugal's intellectual landscape, particularly when compared with the views on science and education of people like António Sérgio $(1883-1969)^{67}$ or

\footnotetext{
${ }^{64}$ Leo Testut, Compendio de Anatomia Descritiva, translated from the 15 th French edition, revised and corrected by A. Latarjet (Barcelona, 1900).

${ }^{65}$ Harry W. Paul, The Sorcerer's Apprentice. The French Scientist's Image of German Science, 18401919 (Gainesville, FL, 1972).

66 It was at the Faculty of Medicine that Alsatian chemist Adolphe Wurtz lectured and established a research school. He eventually became the faculty's Dean. Wurtz believed that all the faculty's specialties should have their own laboratories. In 1868, in his capacity as Dean, he was sent by Victor Duruy, Minister of the Second Empire, to Germany, a country to which he was culturally close and where he had studied under Liebig. The report on this mission was published in 1870 and was later quoted by Celestino da Costa in his address to Sociedade de Geografia. Adolph Wurtz, Les Hautes Études Pratiques dans les Universités Allemandes (Paris, 1870); Celestino da Costa, O Problema da Investigação Científica em Portugal (Coimbra, 1929).

67 António Sérgio was an essayist who wrote for various political magazines, including Seara Nova, of which he became editor in 1923 . He was a supporter of the cooperative movement, which he saw as a means to educate the masses and to change thinking and advance Portuguese society. He opposed the Estado Novo regime and took part in movements in support of non-totalitarian socialism.
} 
Abel Salazar. In contrast to Sérgio, Celestino da Costa and Ferreira de Mira, who were both scientists, adopted a more pragmatic approach. They did not use philosophy to support their views and avoided being dragged into polemics. Their approach was also different from that of Abel Salazar, who had adopted the logical positivism of the Vienna Circle and could not resist a good controversy. With respect to university education, Ferreira de Mira and Celestino da Costa's views echoed Alfredo Bensaúde's $(1856-1941)^{68}$ plans for engineering, a fact that they both acknowledged ${ }^{69}$

Ferreira de Mira, who was a scientific researcher but also a politician, journalist, and publicist, wrote a significant number of articles on university and higher education. These articles, which he called 'scientific propaganda', were mainly published in the daily paper A Lucta, edited by Manuel de Brito Camacho (18621934) ${ }^{70}$ between 1912 and $1918 .{ }^{71}$ They were written for the general public, unlike those published by Ferreira de Mira in Seara Nova ${ }^{72}$ between 1940 and 1943, which concerned new scientific developments and were addressed to Portugal's intellectual elite.

Ferreira de Mira's articles in A Lucta had a clearly ideological tone and were published at a crucial time, making him the main herald of Athias's research school in Portuguese society. He kept writing on these topics for newspapers during the Salazar period, particularly in Diário de Noticias, ${ }^{73}$ where he managed to publish front-page articles expressing these same views with elegance and often with irony. ${ }^{74}$ With his roundabout style, he was able to circumvent the censorship of Salazar's regime. He also gave explicit support to his colleague Celestino da Costa, whom he

${ }^{68}$ Alfredo Bensaúde was a Portuguese geologist who graduated from Gottingen in 1881. He was a lecturer at Instituto Industrial e Comercial de Lisboa until 1910 when Brito Camacho, Minister for Economic Development, asked him to reform engineering education in Portugal. He actively promoted the adoption of new teaching methods and a renovation of teaching staff, thus winning an international reputation for Instituto Superior Técnico, established in 1911,.

69 Matias B. Ferreira de Mira, 'A Extensão Universitaria', A Lucta (3 September 1917).

70 Manuel de Brito Camacho was a doctor, journalist, and politician. He was a staunch supporter of liberal policies and founded the newspaper A Lucta in 1906 to promote his views. He also became a state figure when he was appointed Minister for Economic Development in 1910 and was elected leader of the unionist republicans. He was also appointed High Commisioner for Mozambique.

${ }^{71}$ Ferreira de Mira eventually became editor of the newspaper when Brito Camacho was appointed the Republic's High Commissioner for Mozambique. A Lucta ceased publication in 1922, and Ferreira de Mira stopped writing for newspapers. He took it up again between 1945 and 1947 in Jornal do Comércio, O Diabo and Diário de Noticias, where he published articles along the lines of those previously published in $A$ Lucta .

72 Seara Nova was a Portuguese magazine for 'theory and criticism'. It was edited by republican intellectuals between 1921 and 1982. Its goal was to intervene in the country's political debates without becoming involved in party politics. The articles published by Ferreira de Mira in the magazine were collected in two volumes. Ferreira de Mira, Palestras Científicas, in Cadernos de Seara Nova, 1940 (Lisbon, 1940) and Curiosidades Científicas (Lisbon, 1943).

${ }^{73}$ Diário de Notícias is a daily paper, established in 1864 , that carries national as well as international information on cultural topics.

${ }^{74}$ Examples of his style include Ferreira de Mira's article on IAC: 'the name [Junta Nacional de Educação] does not include the adjective 'alta' (high) which is always somewhat suspect and slightly arrogant'. Matias B. Ferreira de Mira, 'O Instituto para a Alta Cultura', Diário de Notícias (26 July 1952). Another example can be found in an article with an ironic title in which he states:

Ideally - and I say this humbly — secondary education would be compulsory and free, as happens by law with primary education. But I am not unaware that human ideals are like a light that we see in the distance and that we strive to reach but never do.

Ferreira de Mira, 'Outubro Mês Festivo para a Educação Portuguesa', Diário de Notícias (25 October 1952). 
considered 'one of the university professors who has dedicated most time to higher education matters', ${ }^{75}$ and to Costa's attempt to influence ortugal's science policy while presiding over the Institute for High Culture (IAC).

There are recurrent themes in the articles published by Ferreira de Mira during World War I in A Lucta: the need to engage in science "propaganda" ${ }^{76}$ and to internationalize science; the roles of pure and applied science; ${ }^{77}$ the need to link industry and the universities; the role of the private sector (industrialists and millionaires) in funding research; the superiority of German science, ${ }^{78}$ the scientific backwardness of Latin countries, particularly France, ${ }^{79}$ and measures to overcome this state of affairs. On all these topics, Ferreira de Mira echoed the debates that were taking place in Europe and singled out those countries that were witnessing a scientific renaissance under a German cultural influence. ${ }^{80}$

Celestino da Costa, who was deeply influenced by the positivist ethos of the Portuguese republican regime, saw himself as an apostle of science. ${ }^{81} \mathrm{He}$ published a limited but significant number of pamphlets on policy issues, usually in the form of speeches on university education and scientific research. ${ }^{82}$

Like Ferreira de Mira, he favoured the German university model. He believed that the flourishing of German universities and culture was largely due to the Reformation and considered the establishment of the University of Berlin in 1809 a historical landmark, a view he shared with many of his European colleagues. ${ }^{83}$ In some of his texts, Celestino da Costa quotes that university's celebrated motto, Lern-und lehrfreiheit (freedom to learn and to teach) in a style that echoes an article published by Helmoltz in France some 60 years before. ${ }^{84}$

Celestino da Costa identified some of the causes of Portugal's scientific backwardness: the lack of teachers who could be models for their students; the absence of a scientific tradition; the absence of steadfastness and of love for work, 'a utilitarian attitude blown out of proportion and in stark contrast with our inability for practical life'; 'the exaggerated importance ascribed to erudition and rhetoric'; geographical isolation; 'the negative influence of the French educational model'; and 'the fundamental issue of teachers' low pay'. ${ }^{85}$

75 Matias B. Ferreira de Mira, 'Carta ao Dr. Moura Pinto', in Cartas de Longe (Lisbon, 1932), p. 74.

76 A word often used by Ferreira de Mira.

77 Matias B. Fereira de Mira, 'O Ensino Superior', A Lucta (12 February 1917).

78 Matias B. Ferreira de Mira, 'A Expansão Intelectual', A Lucta (21 de May 1917).

79 Matias B. Ferreira de Mira, 'Agua Mole', A Lucta (26 November 1918).

${ }^{80}$ Matias B. Ferreira de Mira, 'Os Nossos Vizinhos', A Lucta (12 October 1917).

81 In his unpublished autobiography 'História de uma experiência', he wrote:

During the winter of 1902-1903, when I was in my third year and while recovering from an illness, I became aware of the shortcomings of the university and of education generally and what could be done about them, involving both in a movement for a new science... I decided to become an apostle of the idea.

82 Ramón y Cajal, S., 'Recuerdos de mi Vida', in Augusto Celestino da Costa, 'Ramón y Cajal (1852 1934)',O Médico (separata), 126 (1954), 6. Before this speech was published, Celestino da Costa had already published a similar article albeit on medical education in Medicina Contemporânea, in 1917, Augusto Celestino da Costa, 'Ensino Médico e Universidades', Medicina Contemporânea (separata), 1719 (1917), $1-29$.

83 Augusto Celestino da Costa, op. cit. (31), pp. 17-18.

${ }^{84}$ Hermann Helmoltz, 'La Liberté Académique dans les Universités Allemandes', Revue Scientifique, 14 (1878), 813-20.

${ }^{85}$ Augusto Celestino da Costa, op. cit. (31), pp. 49-57. 


\subsection{Involvement in active politics}

Some members of Marck Athias's school held important positions in Portuguese public life, including Athias himself and his disciples Ferreira de Mira, Azevedo Neves (1877-1955), Joaquim Fontes, and Celestino da Costa. They propagated their ideas and were able to extend their influence, not only among the Portuguese scientific community but also to wider audiences. In this way, they contributed to the consolidation of the research school and inspired a series of initiatives taken at the highest political level, such as the creation of JEN. This institution was designed to promote a national policy for science teaching and research so they could be perceived by the next generation as instruments of paramount importance to the progress of the country in the first half of the twentieth century.

Ferreira de Mira's influence was felt through his activities as a Member of Parliament, a Councillor in Lisbon's city council, a journalist, and a publicist. Azevedo Neves, who became Secretary and Minister for Foreign Affairs and director of the Institute of Legal Medicine (Instituto de Medicina Legal), was instrumental in the allocation of funds to the Faculty of Medicine of Lisbon, the Institute of Pathological Anatomy (Instituto de Anatomia Patológica), and the Portuguese Institute of Oncology. ${ }^{86}$ Finally, Joaquim Fontes and Celestino da Costa played an important role in JEN.

The role played by Athias and his disciples in the political arena was fundamental in obtaining funds, in publicizing ideas associated with the modernization of higher education, and even in drawing up national scientific policies. Their activity in this context was decisive in ensuring the success and implementation of the research programme of Athias's school of histophysiology.

\section{Concluding remarks}

The success of Marck Athias' research school of histophysiology was largely due to the fact that it was led by a physician who had been trained according to European scientific standards. Athias was strongly influenced by Santiago Ramón y Cajal and by his research into the histophysiology of the nervous system, which at the time caused considerable controversy. Athias was welcomed to Lisbon in 1897 by Miguel Bombarda, like Athias a supporter of Cajal's neuron theory. With Bombarda's patronage, he began his academic career at the Medical School of Surgery and was eventually appointed to the chair of physiology at the Faculty of Medicine of Lisbon, in 1911 .

Athias, having lived in Paris, was aware of the importance of training disciples and starting a tradition. This is why he surrounded himself with young students as soon as he began carrying out research in Portugal. Those students were often recruited from the ranks of medical schools and were keen to engage in scientific careers. They shared a common vision about research and the university and thus made up a solid, coherent group with its own identity.

The research programme undertaken by Athias's school was initiated with investigations into the histophysiology of the nervous system in 1897, a field to which Athias himself had originally contributed. It was extended to include general histophysiology, physiology, physiological chemistry, and histopathology. It may be

86 Álvaro Tavares, O Instituto para a Alta Cultura e a Investigação Cientifica em Portugal (Lisbon, 1951). 
claimed that the methods and techniques of histophysiology migrated to new areas of ignorance, in particular to endocrinology. As regards the histology of the nervous system, Athias's school focused on neural development and cellular infiltrations in the brain; in histophysiology, it studied the endocrine glands; the school also investigated the physiology of muscles, glands, and certain organs such as the kidneys and heart. Regarding physiological chemistry, chemical explanations were sought for the physiological phenomena being studied. Finally, in histopathology, the school carried out oncological studies in which tumours were induced in selected strains of mice.

Athias's research school promoted ideas that were inspired by positivism and republican ideals. Athias also proposed a model for university education and research based on the German example. He and his disciples advocated researchbased university education, in which research schools would play a fundamental role. Furthermore, they were strongly committed to the dissemination and promotion of scientific ideas in society at large. They argued for scientific exchanges between people and institutions, as well as for the establishment of scientific societies and specialized journals. In this respect, Athias's school was instrumental in the establishment of the first biomedical societies in Portugal. Furthermore, it controlled the publishing activities of these societies; his research school realized that both were key factors in the emergence of new specialties and in the consolidation of the professional identity of its practitioners.

In addition to its scientific research programme, the agenda of Athias's research school also included policy issues, particularly the advancement of scientific research and university education in Portugal.

His school spans two key periods in twentieth-century Portuguese history and politics. The republican regime favoured the principles that guided the school. Thus, early developments within the context of an overhaul of medical education, such as the establishment of the University of Lisbon, in 1911, and of JEN, in 1929, were of paramount importance to the success of the school. The Estado Novo, despite being unfavourable to such a programme, was unable immediately to suppress the tradition that the school had inaugurated. Athias's research school thus became a pillar in the scientific community, up to the second generation of its disciples. In ideological terms, it became a landmark and reference for intellectuals who lived through the darkest years of the dictatorship.

Marck Athias's research school can be considered a successful endeavour in the Portuguese context, despite the fact that it emerged nearly half a century after the movement which led to the establishment of research schools throughout Europe. Between 1897 and 1946, the school played a key role in the development of related medical specialties at the Faculty of Medicine of Lisbon. The school did not disappear with the death of its leading figure. Rather, its disciples carried forward the new specialties that emerged from its research programme.

The criteria put forward by Morrell, Geison and Fruton to study research schools are applicable to Athias's histophysiology school. The cognitive framework generated by Athias's programme was responsible for the emergence of new scientific disciplines in the Portuguese medical context. In the long run, these disciplines consolidated methods and techniques which migrated to other scientific areas, as was the case with Portuguese experimental endocrinology, which emerged in the 1950s. This process reinforces the view that research schools are fundamental elements in the process of discipline-building. 


\section{Acknowledgements}

A word of gratitude is due to Ana Carneiro, Ruy E. Pinto, and A. M. Nunes dos Santos, for suggesting this subject and for their comments, and to Luis Correia Botelho and José David-Ferreira, for providing me with references that are not available in Portuguese libraries. I would also like to thank Luis Pinto, for the translation of this article, and Paula Faia of the Bento da Rocha Cabral's Scientific Research Institute, for her efficient and kind assistance on the Historical Archive and Library. To Ana Carneiro, I am most grateful for her generous suggestions and linguistic corrections and also to Trevor Levere and Paul Covill, for their linguistic revision. 